\title{
BARRIERS AND CHALLENGES IN INCREASING RURAL EMPLOYMENT: LABOUR RESOURCES AND SELECTED POLICY INSTRUMENTS. THE CASE OF EU COHESION POLICY AND COMMON AGRICULTURAL POLICY INTERVENTIONS IN POLAND
}

\begin{abstract}
Michal DUDEK, Institute of Agricultural and Food Economics, National Research Institute, Świętokrzyska St., 00-002 Warszawa, Poland, dudek@ierigz.waw.pl (corresponding author)

Bożena KARWAT-WOŹNIAK, Institute of Agricultural and Food Economics, National Research Institute, Świętokrzyska St., 00002 Warszawa, Poland Bozena.Karwat-Wozniak@ierigz.waw.pl

An important feature of many rural markets is the over-supply of labour. An insufficient number of jobs in rural areas is usually associated with the shortage of capital, companies, consumers and skilled workers, i.e. limited impact of the agglomeration effect. Additionally, in regions with structural changes in agriculture, the phenomenon of increased or hidden unemployment is visible. One of the important objectives of labour market policy in Poland was a promotion of employment, especially in peripheral, poor and agricultural territories. Along with the accession of Poland to the EU, both agricultural and cohesion policy instruments supported by the structural funds have also been aimed at resolving the problems of rural labour markets. They concerned mainly the diversification of agricultural activities, support of entrepreneurship, as well as development of knowledge and skills. The paper considers the barriers and challenges in increasing employment in rural Poland. In particular, the changes on local rural labour markets and the influence of relevant policy tools thereon have been studied. The study is based on the quantitative and qualitative analysis of the public statistics and information on the implementation of selected EU CAP and Cohesion Policy instruments in Poland from the period 2007-2014 and the literature of the subject. The study showed that, despite the favourable economic situation and the effects of projects aimed at creating and maintaining non-agricultural jobs in rural areas supported by the EU founds, the rural employment rate and the number of people employed in agriculture did not increase significantly. In this context, the paper provides the explanation of limited improvements in terms of rural employment and policy offers recommendations in this area.
\end{abstract}

Keywords: rural employment, labour resources, EU, Cohesion Policy, Common Agricultural Policy

\section{INTRODUCTION}

The characteristic of rural labour markets is the predominance of demand over supply. This situation generally results from the shortage of economic entities and capital, which are concentrated in densely populated areas with developed infrastructure. Economy sectors traditionally related to rural areas, such as agriculture, forestry, fishing, tourism and recreation, provide a significant number of jobs. However, they generally do not offer a sufficient number of appropriately paid jobs for the rural population (Chmieliński, 2013). This is particularly true of agriculture, which is a specific area of economic activity undergoing structural changes. They involve processes of concentration of productive resources and intensification and specialisation of production, which are associated with the flows of people employed there to other more productive sectors, or often with their economic passivity. The characteristics of rural economy are determined by the mobility of rural inhabitants, which takes the form of daily commuting to work or short or long-term migrations. They are also an important stimulus for the rural population to change their place of residence. This applies in particular to the peripheral areas that are being depopulated and where social and living problems are significant. On the other hand, different tendencies take place in towns located in the vicinity of urban centres or villages with attractive locations (Marini, 2006). Local labour markets are generally relatively more sustainable due to the presence of investments, business entities related to cities and increased demand of incoming people for products and services. In consequence of these processes, similar trends emerge there as in the urban labour markets, and they involve the professionalisation and polarisation of employment (Green, 2016).

An increase in professional activity and improvement of qualifications of the rural population have been indicated as one of the key development challenges in Poland for a long time. This process was supposed to be done by encouraging the flow of workers from agriculture, including the elimination of barriers for occupational, social and spatial mobility. Interventions taken under the development policy were supposed to contribute to increasing employment in rural areas

Copyright (C) 2017 The Authors. Published by Aleksandras Stulginskis University. This is an open-access article distributed under the terms of the Creative Commons Attribution License (CC-BY 4.0), which permits unrestricted use, distribution, and reproduction in any medium, provided the original author and source are credited. 
while reducing the scale of unemployment and the participation of people working in agriculture (employment deagrarianisation) (National Strategic.., 2007).

The aim of the study was to analyse the determinants for increasing occupational activity on the rural labour market in Poland. Changes on local labour markets and the impact exerted on them by policy instruments aimed at the promotion of professional activity were analysed in particular. The study was based on the quantitative and qualitative analysis of data from official statistics and information on the implementation of selected CAP instruments and EU cohesion policy in 2007-2015 in Poland. The premises, functioning and results of these interventions have been described. The paper consists of the following parts. The first subchapter describes the sources of data and information as well as the research methods used. The next part describes selected causes of public support for increasing employment in rural areas in Poland. Next part explains the functioning and effects of implementing measures No. 311 Diversification into nonagricultural activities (hereinafter referred to as Diversification), 312 Establishment and development of microenterprises (hereinafter referred to as Establishment and development) and 413 Implementing the Local Development Strategies (hereinafter referred to as Implementation) within the framework of the Polish Rural Development Programme 2007-2013 (RDP 2007-2013) and selected instruments of national and regional operational programmes financed under the EU Cohesion Policy funds, whose were directly formulated goal was to increase professional activity within rural areas. The discussion and summary section evaluates the functioning of the above-mentioned instruments in Poland and suggests solutions to be applied in the following years.

\section{RESEARCH METHODS}

Data published by the Agency for Restructuring and Modernisation of Agriculture (hereinafter referred to as ARMA), the paying agency that implements instruments in Poland that are co-financed by EU funds for the implementation of the RDP 2007-2013, as well as documents and legal acts related to monitoring the implementation of the RDP 2007-2013 and published by the Ministry of Agriculture and Rural Development (hereinafter referred to as MARD) were used for the purposes of this paper. The data to illustrate the changes on the rural labour market in Poland and its differentiation were taken from the Central Statistical Office (CSO). On the other hand, the information about the use of EU Cohesion Policy funds through the Structural Funds was obtained from available databases and evaluation papers. In addition, EU and national legal acts and strategic documents were used in the paper.

The research uses the method of quantitative and qualitative analysis of secondary statistical data, as well as the contents of strategic documents, legal acts and expert studies. The paper examines mainly the employment rate, i.e. the percentage of employed persons in the population aged 15 and over. Areas according to administrative definitions or the ones defined for specific public intervention programmes were considered rural areas.

\section{RESULTS}

\section{Strategic premises of increasing rural employment in the eu and poland}

High employment is promoted and supported by the EU policies. This activity is based on the Treaties and is of major importance as a rule when defining various action areas, from the internal market, through economic, social and territorial cohesion to agriculture. EU labour market activity is primarily to develop a uniform employment strategy by the Member States (taking action for a high level of qualification and training of workers and their ability to adapt). Employment growth policy formulated this way (in the form of conclusions, guidelines, recommendations and reports, as set out in Title IX of the Treaty on the Functioning of the European Union) is to serve the basic objectives of the EU (Article 3 of the Treaty on European Union) (McCann, 2015).

Activities focused on increasing professional activity were an important element of EU policy in 2007-2013, as set out by the Lisbon Strategy, and in particular by the renewed version of this document and the objectives of the second pillar of the CAP. It was pointed out in CAP documents that it is necessary to introduce changes in rural areas by increasing human potential, increasing employment and developing non-agricultural sectors in order to reverse the economic and social decline and depopulation of rural areas (Council Regulation..., 2005). The aim of the Lisbon Strategy was to create a competitive and knowledge-based economy that provides jobs. It was assumed at the EU level that the level of employment shall be achieved at $70 \%$ (or $60 \%$ for women). The strategic objective of the Cohesion Policy under implementation in Poland during the 2007-2013 programming period was to generate conditions for increasing the competitiveness of the knowledge-based economy and entrepreneurship ensuring an increase in employment and an increase in the level of social, economic and spatial cohesion (National Strategic.., 2007). The strategic objective outlined this way comprised six horizontal specific objectives. One of them applied to agriculture and the rural economy: Equal development opportunities and supporting structural changes in rural areas.

Structural changes in agriculture, including streamlining the employment structures, were to be promoted by the use of CAP instruments, in particular its second pillar (e.g. by creating conditions for the development of entrepreneurship and new jobs outside agriculture). On the other hand, Cohesion Policy instruments (reduction of disproportions in human resources development, vocational training for people leaving agriculture, promotion of entrepreneurship) were involved for better support for non-agricultural rural development, including increased non-agricultural professional activity. Not only European and national (budgetary) financial support has been chosen as a means of achieving this strategic objective, but also institutional and legal/regulatory actions (public finance reform, business conditions, labour market policy) (National Strategic.., 2007). Therefore, interventions to increase employment in the EU and in Poland could be divided 
into two intervention groups. The first one covered changes in the instruments that created supply on the labour market. One of the goals was to increase the competitiveness of workers, to modernise social security systems, to develop education and training systems tailored to the needs of various social groups. The second group of reforms was related to instruments that created demand on the labour market, i.e. facilitating the business of the sector of small and medium enterprises (reducing operating costs, reducing administrative barriers, financial support), promoting quality jobs and good employment conditions (e.g. friendly environment, equal opportunities, work safety, continuous professional development, flexible organisation), as well as support for the mobility of workers. The next part of the paper presents changes in the overall scale of rural employment in Poland during the implementation of the EU 2007-2013 financial perspective and their determinants.

\section{Increasing rural employment in Poland: selected achievements and barriers}

The employment rate in Poland increased slightly from 49.2 to $51.6 \%$ in 2007-2015. The NSRF target assumed for the period in question (53\%) has not been achieved (Table 1). A small increase in employment has been observed both among men and women in rural areas. These figures were below the target levels, i.e. $44 \%$ for women and $62 \%$ for men. Regardless of the positive growth trend of rural employment in Poland, it should be pointed out that its level was on average lower than for cities and significantly lower than in the EU-27. The developments on the rural labour market, including the scale of employment in Poland in 2007-2015, were influenced by a number of macroeconomic, sociodemographic and institutional factors. Their impact on employment in rural areas was both positive and negative.

Regardless of the unfavourable effects of the economic crisis, which was manifested by the slowdown in the growth rate of the global product and a decrease in the number of jobs, economic growth was observed throughout the period in question, which proved the good situation of economic entities forming the demand side of the labour market.

Table 1. Selected changes in rural labour market in Poland (in \%), 2007-2015*

\begin{tabular}{|c|c|c|c|c|c|c|c|c|c|c|}
\hline Specification & 2007 & 2008 & 2009 & 2010 & 2011 & 2012 & 2013 & 2014 & 2015 & target value \\
\hline share of employment in agriculture & 14.8 & 14.0 & 13.3 & 12.9 & 12.7 & 12.6 & 12.0 & 11.5 & 11.5 & 10.6 \\
\hline rural employment rate & 49.2 & 50.7 & 50.8 & 50.4 & 50.5 & 50.4 & 50.3 & 50.9 & 51.6 & 53.0 \\
\hline women & 41.2 & 42.2 & 42.2 & 42.0 & 41.9 & 41.5 & 41.3 & 42.2 & 42.7 & 44.0 \\
\hline man & 57.5 & 59.5 & 59.8 & 59.0 & 59.5 & 59.4 & 59.4 & 59.8 & 60.6 & 62.0 \\
\hline rural unemployment rate & 9.2 & 7.0 & 8.0 & 9.3 & 9.6 & 10.2 & 10.4 & 9.5 & 8.0 & 13.5 \\
\hline
\end{tabular}

${ }^{*}$ Since 2010 indicators were calculated according to the new methodology and the new base for data generalisation, which limits their comparability. Source: (Sprawozdanie, 2015) and http://strateg.stat.gov.pl/.

The positive economic situation was reflected by the scale of rural unemployment, which remained stable and relatively low. It did so regardless of the shrinking of the working population in agriculture. The percentage of this group in the total number of employed in Poland in 2007-2015 decreased from 15 to $12 \%$. The level of registered unemployment was low among the farming population. This was due to the legal solutions and the family character of the organisation of agricultural production in Poland. It was associated with high professional activity of members of these families and at the same time with the provision of a small amount of work on farms by a significant group. These were generally workers who were unnecessary from the point of view of the needs of the farms, which were in fact unused labour resources (Karwat-Woźniak, 2015). The relatively high demand for work was promoted by limited supply caused by, inter alia, a significant outflow of the working population from rural areas. It applied in particular to the foreign migration motivated by earnings. It is estimated that 2 million people stayed abroad. Over one third of them lived in rural areas. Less than two-thirds of this population were rural residents (Frenkel, 2016). On the other hand, the aging of the rural population negatively affected the rural employment rate in 2007-2015. The percentage of people in the post-working age population increased from 13 to 17\% in 2006-2014 (Obszary wiejskie..., 2016). The shape of the retirement and disability pension system, together with low wages and often unfavourable working conditions, increased the tendency to exit the labour market. These trends will be strengthened in the future. Demographic processes (according to the forecast for 2014-2050 in rural areas, the proportion of people in the post-working age population will increase from 16 to $34 \%$ ) and institutional labour market changes (e.g. lowering the retirement age from 67 to 65 for men and 60 for women) will contribute to it. It should be added that the preferential system of direct and indirect taxes on agriculture (exclusions, reliefs, exemptions), favourable conditions for retirement security (low contributions) and the healthcare system (largely financed by the state) were a barrier to increasing non-agricultural employment of the rural population and a factor conducive to work in agriculture, including the persistence of a high hidden unemployment in this sector. At the same time, an insufficient level of development of care and education infrastructure in rural areas throughout the period in question should be considered as an important determinant of occupational inactivity, in particular among rural women.

\section{Effects of the implementation of selected CAP and Cohesion Policy instruments for non-agricultural rural employment in Poland}

Increasing the scale of rural employment in Poland in 2007-2015 was promoted by the measures taken under the Cohesion Policy and CAP of the EU. These two streams of activities were to be complementary. The identification of common areas of intervention has resulted in the need to develop the "demarcation lines" in order to limit the implementation of specific types of projects to individual operational programmes. The project value was adopted as the 
basic criterion for the delimitation, where higher-cost projects were implemented, as a rule, under Cohesion Policy programmes (Rural Development..., 2007).

The conducted research showed that in consequence of implementing the instruments of EU Cohesion Policy in Poland (NSRF), 186,000-282,000 jobs were created at the beneficiaries (after conversion into full-time equivalents, the value increased to ca. 190,000) (Wpływ realizacji..., 2016). Most of them, namely about 98,000 full-time equivalents (FTE), were created at the recipients of support as a result of implementing Regional Operational Programmes (98,000). The contribution of Operational Programme Infrastructure and Environment was lower in this regard (about 52,000 FTEs) and for Operational Programme Human Capital (about 35,000 FTEs). The impact observed for the Operational Programme Development of Eastern Poland was relatively low (4,000) (Wpływ realizacji..., 2016). It is estimated that $30 \%$ of the total number of jobs created as a result of a Cohesion Policy intervention has been created in rural areas and towns with up to 5,000 residents (Wpływ realizacji..., 2016). However, most of them were generated in the public sector (two thirds). These were primarily aimed at implementing projects co-financed by the EU. Only a small part of the jobs remained after the completion of the projects. The projects under the Cohesion Policy directly aimed at the increase of rural employment were implemented mainly by Operational Programme Human Capital (OP HC), Operational Programme Development of Eastern Poland and Regional Operational Programmes. One of the direct forms of improvement of the employment and labour market situation under the Cohesion Policy was support for start-ups implemented within the former programme. This assistance made it possible to establish 246,000 companies. It can be estimated that about one-third of them were established in rural areas (Wpływ realizacji..., 2016).

The projects co-financed by the European Social Found and addressed to economically inactive people were characterised by high employee efficiency. Over every second unemployed found a job half a year after the completion of the project. The inhabitants of rural areas represented a significant part of the recipients of the projects implemented under the Operational Programme Human Capital. On the other hand, farmers participated in them to a small extent (FundEko, 2013). Nevertheless, it was ascertained on the basis of the results of the conducted evaluation studies that there was no correlation between the interventions made and the dynamics of changes in the number of economic entities or the unemployed in rural areas. The intensity of entrepreneurship support was relatively higher in economically developed localities, where a relatively low unemployment rate was recorded earlier. Changes on the labour market were largely dependent on factors other than the projects financed by EU funds (FundEko, 2013).

When considering the CAP three RDP measures directly promoted an increase in the employment in the programming period 2007-2013. Assistance for taking up or developing non-agricultural or agricultural activities in the field of production and services by farmers, family members and spouses of farmers was provided the Diversification measure. The goal of this intervention was to create non-agricultural sources of income and to promote employment outside agriculture in rural areas (an employment opportunity in the taken up or developed activity was provided for). Half of the costs incurred were reimbursed up to PLN 100,000 (EUR 25,616) as part of the assistance. In 2007-2015, the support was provided to 15,300 people who have implemented 15,700 projects (Sprawozdanie, 2016). Over 99\% of the EAFRD funds allocated for the implementation of the measure were used. EU support was most often allocated for the provision of farm and forestry services (10,900 projects, which accounted for $70 \%$ of all operations under Measure 311$)$. The research conducted among the beneficiaries indicated that thanks to the granted subsidies, 13,800 jobs were created outside agriculture, of which 11,900 were permanent (Sprawozdanie, 2016).

Another RDP measure aimed at increasing rural employment was creation and Establishment and development. Assistance for the start-up or development of business activities could be granted to natural or legal persons or organisational units without legal personality. The amount of assistance varied from PLN 100,000 to PLN 300,000 (from EUR 25,600 to EUR 76,800) depending on the number of jobs created (from 1 to 3) and could represent up to 50\% of project costs. Support under the measure was provided to 14,500 projects involving the establishment and development of companies (most of the assistance was granted to the already existing entities), which resulted in the creation of 24,000 non-agricultural jobs. Beneficiaries of this measure included the entities providing services to the public (construction and installation, agricultural, tourist, leisure and sports services) (Sprawozdanie, 2016).

Stimulating job creation in rural areas was the goal of the Local Development Strategy. As part of the implementation of the strategy, financial resources were allocated to the implementation of Axis 3 Diversification and Establishment and development (LAGs selected projects to be covered by support). Under the LEADER approach, support was provided to 1,800 people involved in farms taking up additional economic activity (over half of the cases in the form of services for agriculture and forestry) and 1,400 projects taken by new and existing non-agricultural economic entities. 942 new jobs were created with the support under the EAFRD (Sprawozdanie, 2016).

\section{DISCUSSION AND CONCLUSIONS}

Differentiation of the labour market is a characteristic of rural areas in Poland. In some regions, there are mainly villages with developed non-agricultural functions, where, despite economic fluctuations, relatively high occupational activity, a low unemployment rate and a low employment rate in agriculture can be observed. In other typically agricultural and peripheral areas, the agricultural sector remains an important place of work. Due to unfavourable locations, low impact of the agglomeration effect and insufficient development of various rural functions, there is a shortage of jobs. As a result, subsistence of a large part of the population is dependent on farming or social transfers. A small economic potential of many farms and the lack of development activities on the part of the users results in income generated at a much lower level than the average in the economy, and the chances of its growth are negligible. In many cases, farms fulfil social functions in such 
a case because they do not provide a place for professional activity, but give an opportunity to benefit from the social and health insurance and tax system, as well as CAP subsidies (direct payments, RDP measures). The regulations in force and the shape of the social policy did not favour the economic activity of the rural population, including the inhabitants of rural areas without farms. At the same time, the chances of getting out of unemployment reduced the situation on the labour markets, which was often associated with low wages and unfavourable employment conditions.

The period after Poland's accession to the EU was marked by profound changes in the rural labour market. The number of people working in agriculture has significantly decreased. The number of farms has also decreased. Regardless of these changes and the improvement of the labour market situation, among other things in relation to the economic upturn, it is estimated that professional activity in rural areas in 2007-2015 was too low. The NSRF targets for employment have not been achieved. It must be pointed out in the first place that the economic slowdown was an obstacle to its implementation. At the same time, the issue of increasing employment is complex and requires long-term economic and institutional changes, including structural ones. In this context, it should be pointed out that an increase in employment in rural areas depends primarily on the availability of non-agricultural jobs and the elimination of incentives favouring occupational inactivity, retirement, or staying in the agricultural sector.

The issue of supporting rural employment is a derivative of public choice. Public intervention in this area can be considered as controversial and disrupting an effective market mechanism by misallocating goods. First of all, it was an expenditure of public funds, the effectiveness of which was limited. The majority of created jobs did not last after the end of obligatory project duration or public financial support period. However, the intervention within the EU CAP and Cohesion Policy contributed to the emergence of a direct effect of creating jobs and incomes of a significant number of beneficiaries. Moreover, these projects induced the supply-side effects. This impact was generally postponed and applied to improving the knowledge and skills of rural labour resources (Ocena wpływu, 2015). Undoubtedly, there was a partial improvement in the knowledge and skills of beneficiaries of the measures aiming at increasing rural employment within operational programmes and RDP. All these initiatives could, directly or indirectly, induce positive stimuli in the rural labour markets.

\section{REFERENCES}

1. Chmieliński, P. 2013. Ludność wiejska na rynku pracy. Zarobkowanie, bezrobocie, przedsiębiorczość i praca za granicą w latach 2005-2011, IERIGŻ-PIB, Warszawa. [In Polish]

2. Council Regulation no 1698/2005 of 20 September 2005 on support for rural development by the European Agricultural Fund for Rural Development (EAFRD)

3. Frenkel, I. 2016. Ludność wiejska. In: Wilkin J., Nurzyńska I. (eds.) Polska wieś, 2016. Raport o stanie wsi, Scholar, Warszawa, pp. 21-61. [In Polish]

4. FundEko Inicjatywa Dobrych Praktyk. 2013. Wpływ Wspólnej Polityki Rolnej i Polityki Spójności na rozwój obszarów wiejskich. Raport końcowy, Available at http://www.minrol.gov.pl/Wsparcie-rolnictwa/Program-Rozwoju-Obszarow-Wiejskich-20072013/Dokumenty-analizy-raporty/Analizy-i-raporty (Accessed on 02/05/2017). [In Polish]

5. Green, A. 2016. Changing Dynamics of Rural Labour Markets. In: Shucksmith, M. Brown, D.L (eds.). Routledge International Handbook of Rural Studies, Routledge, New York, pp. 143-151.

6. Karwat-Woźniak, B. 2015. Zasoby pracy w polskim rolnictwie indywidualnym i ich wykorzystanie. Roczniki Naukowe Ekonomii Rolnictwa i Rozwoju Obszarów Wiejskich, Vol. 2, No. 1, pp. 70-84. [In Polish]

7. Marini, M.B., Mooney, P.H. 2006. Rural economies. In Clocke, P., Marsden, Mooney, P. (eds.) The Handbook of Rural Studies, Sage, London, Thousand Oaks, New Dehli, pp. 91-103. ttps://doi.org/10.4135/9781848608016.n6

8. McCann P. 2015. The Regional and Urban Policy of the European Union. Cohesion, Results-Orientation and Smart Specialisation, Edward Elgar Publishing, Cheltenham. https://doi.org/10.4337/9781783479511

9. National Strategic Reference Framework 2007-2013 in support of jobs and growth. National Cohesion Strategy. 2007. Document adopted by the European Commission on the $6^{\text {th }}$ of May 2007, Warszawa.

10. Obszary wiejskie w Polsce w 2014 r. 2016. GUS, Warszawa. [In Polish]

11. Ocena wpływu Programu Rozwoju Obszarów Wiejskich 2007-2013 na gospodarkę Polski. Raport końcowy, Wrocławska Agencja Rozwoju Regionalnego, Wrocław 2015. [In Polish]

12. Rural Development Programme for 2007-2013 (RDP 2007-2013). 2007. MARD, Warsaw.

13. Sprawozdanie z realizacji Programu Rozwoju Obszarów Wiejskich na lata 2007-2013. 2015. no 9/2015, MARD, Warszawa. [In Polish]

14. Wpływ realizacji NSRO 2007-2013 na poziom i jakość zatrudnienia w Polsce. Raport końcowy. 2016. WYG PSDB Sp. z o.o. and Evalu Sp. z o.o., Ministry of Development, Warszawa. [In Polish] 